\title{
Miten analysoida sitä, mistä ei voi kertoa? \\ - Käsikirja humanistiseen traumatutkimukseen
}

Colin Davis \& Hanna Meretoja (toim.): Routledge Companion to Literature and Trauma. Abingdon \& New York: Routledge, 2020, 496 s.

Colin Davisin ja Hanna Meretojan toimittama käsikirja The Routledge Companion to Literature and Trauma esittelee monenlaisia teoreettisia lähtökohtia ja kirjallisuustieteellisiä analyyseja. Teoksen tarkoituksena on tarjota opas humanistisen traumatutkimuksen historiaan ja teoriaan sekä "demonstroida traumatutkimuksen laajuutta ja elinvoimaisuutta" (s. 6), eikä tarjota yhtenäistä kuvaa humanistisen tai kirjallisuustieteellisen traumatutkimuksen kentästä. Mielestäni teos onnistuu tarkoituksessaan erinomaisesti, ja etenkin traumatutkimuksen historia ja teoria tulevat lukijalle tutuiksi monista eri näkökulmista; traumatutkimus näyttäytyy todellakin laajana ja moninaisena kenttänä. Teos on suunnattu selkeästi niille, joilla on perustietoa kirjallisuustieteestä ja sen käsitteistä, eikä esimerkiksi psykiatreille, joita kiinnostaa ensimmäisiä kertoja laajentaa tietämystään humanistiseen suuntaan.

Teoksen artikkelit voi hyvin lukea myös erikseen, sillä niissä kertautuu - kunkin artikkelin aiheelle tarpeellisella laajuudella - traumatutkimuksen historian keskeiset piirteet. 1830-luvulla junaonnettomuuksien uhrit oireilivat silloiselle tieteelle selittämättömällä tavalla, ja heidän ajateltiin saaneen vammoja selkärankaansa. 1880-luvulla käänteentekevää oli saksalaisen neurologin Hermann Oppenheimin traumaattisen neuroosin käsite, jossa tilaa ei enää ymmärretty pelkästään somaattisena. Ensimmäisen maailmansodan jälkeen, Sigmund Freudin teorioiden myötä trauma alettiin ymmärtää tietoisen mielen välttelemänä ja vaikeasti kerronnallistettavana.

Trauma määrittyykin nykyään ennen kaikkea jälkijättöisyytensä (belatedness) kautta: mieli ei käsittele traumaattista tapahtumaa sen tapahtuessa, vaan palaa siihen hallitsemattomasti jälkikäteen. Toisen maailmansodan ja etenkin holokaustin jälkeen trauman kokeneen positio alkoi vakiintua länsimaisessa kulttuurissa. Sen vakiinnutti 1980-luvulla yhdysvaltalaisen psykiatrian alan tiedejärjestön (American Psychiatric Association) virallistama post-traumaattisen stressireaktion diagnoosi, mikä liittyi lisääntyneeseen keskusteluun erityisesti Vietnamissa taistelleiden sotaveteraanien kärsimistä oireista. Samalla trau- 
matisoituneen henkilön asema alettiin nähdä empatiaa/sympatiaa ja kuuntelemista tarvitsevan positiona eli trauman määrittelyn eettinen ja moraalinen puoli korostuivat. Humanistisen traumateorian sisällä kritiikkiä on esitetty lähtökohdiltaan erilaisten kokemusten näennäisestä yhtenäistämisestä: Kenen annetaan asettua sympatiaa ansaitsevan traumatisoidun henkilön asemaan? Kuka haluaa tämän roolin ottaa? Kenen vaikea kokemus ymmärretään traumaksi? Keskeiseksi kritiikiksi nousee eurosentrisyys, länsimaisten subjektien kokemusten korostaminen ja yleistäminen koko muuta maailmaa koskevaksi.

Käsikirja on jaoteltu viiteen osioon: Lähteet ja inspiraatio; Avainkäsitteet; Kriittiset perspektiivit ja tulevaisuuden suunnat; Genret ja media; Paikat ja tapahtumat. Colin Davisin ja Hanna Meretojan esittelyteksti on selkeä, mielenkiintoinen ja tiivistää laajan aiheen kattavasti. Lähteet ja inspiraatio -osio tarjoaa näkökulmia erilaisiin teoreettisiin ja filosofisiin lähtökohtiin, joista kirjallisuustieteellistä traumatutkimusta on alettu tehdä. Osiosta löytyy muun muassa teoksessa usein viitatun, kirjallisuustieteessä keskeisen traumateoreetikon Cathy Caruthin artikkeli, jossa hän analysoi tarkkanäköisesti kahta psykiatrista tapauskertomusta.

Avainkäsitteet-osion artikkelit käsittelevät kukin tiiviisti mutta kattavasti yhtä avainkäsitettä kerrallaan. Erityisen ajatuksia herättäviä itselleni olivat Erin McGlothlinin tekijän traumaa (perpetrator trauma) sekä Kaisa Ilmosen intersektionaalisuutta käsittelevät artikkelit. McGlothlinin pohdinta traumasta moraalisena kategoriana ja toisaalta väkivallantekijöiden traumaoireiden tunnistamisesta ja tunnustamisesta toivat pintaan sekä tunteita että uudenlaisia suhtautumistapoja lukemiini teksteihin. Artikkeli avasi erilaisia tasoja esimerkiksi luentaani Pajtim Statovcin Bolla-romaanista, jossa trauma kerrostuu ja kertaantuu hahmojen kokemuksissa.

Kaisa Ilmosen artikkelia suosittelen luettavaksi minkä tahansa Genret ja mediat tai Paikat ja tapahtumat -osion artikkelin kanssa. Käsikirjassa yleisesti analysoidaan kirjallisuutta traumaattisista tapahtumista ja asioista, jotka on "yleisesti tunnustettu" traumaattisiksi, kuten Ruandan kansanmurha, 9/11 ja holokausti. Ilmonen hahmottelee artikkelissaan myös uudenlaiselta ja raikkaalta tuntuvaa ajattelua, jossa traumateoria ottaisi huomioon esimerkiksi arkielämässä tapahtuvan jatkuvan syrjinnän, jota marginalisoituihin ryhmiin kuuluvat kohtaavat, ja tämän tuoman mahdollisen traumatisoitumisen. Ajatus poikkeaa perinteisestä syyllinen-uhri -ajattelusta, eikä sovi myöskään nationalistiseen käsitykseen traumatisoiduista sotilaista, jotka kärsivät uhrauduttuaan maansa turvallisuuden puolesta.

Kriittiset perspektiivit ja tulevaisuuden suunnat -osion artikkelit tarjoavat näkökulmia muun muassa kriittiseen posthumanismiin ja uusmaterialismiin sekä kurkistuksen postkolonialismiin kosmologisen trauman käsitteen kautta. Muutamat artikkelit olisivat voineet kasvattaa ja syventää argumenttejaan ammentamalla toisista tieteenaloista. Esimerkiksi Jo Winningin "Trauma, Illness and Narrative in the Medical Humanities" -artikkelia lukiessani odotin, 
että keskusteluun nostettaisiin vammaisuuden käsite ja vammaistutkimuksen teoreettiset keskustelut. Olin myös yllättynyt, että ilmastonmuutoksesta ja traumasta kirjoittava Stef Craps ei maininnut maailman alkuperäiskansoja tai alkuperäiskansatutkimusta. Ilmastonmuutos on vaikuttanut jo pitkään etenkin arktisilla alueilla elävien alkuperäiskansojen elämään, ja toisaalta eri alkuperäiskansojen aktivismi planeetan monimuotoisuuden puolesta on merkittävää ja käänteentekevää.

Genret ja media -osiossa Robert Eaglestonen luvulla "Trauma ja fiktio" on suuri tehtävä: käsitellä sitä, miten trauma ja fiktiokirjoittaminen ovat kietoutuneet toisiinsa. Eaglestonen tekstiä lukiessa ei kuitenkaan voi kuin luottaa kertojaan, joka avaa selkeästi isoja kokonaisuuksia. Hän kirjoittaa kansanmurhan traumasta monista näkökulmista esimerkkinään Joseph Conradin The Heart of Darkness -pienoisromaani. Analyysissa vuorottelevat todellisen Kongon kansanmurhan yhteydet teokseen, teoksen päähenkilön Charles Marlow'n traumatisoituminen väkivaltaisista teoistaan sekä teoksessa nimettömiksi jääneiden kansanmurhan uhrien hiljainen, painostava trauma.

Traumatutkimusta on kritisoitu sen rajoittumisesta länsimaalaisen ajattelun piiriin kuuluviin yhteisöihin. Tämä näkyy myös teokseen valituissa Paikat ja tapahtumat -osion esimerkeissä, joista suuri osa keskittyy eurooppalaiseen tai pohjoisamerikkalaiseen näkökulmaan. Toisaalta esimerkiksi Patrick Deer pohtii kirjoittaessaan Irakin sodasta myös irakilaisten siviilien näkökulmaa ja traumatisoitumista. Tärkeimpänä esimerkkinään hän analysoi tekstiä, jossa on valittu vaieta heidän kokemuksistaan. Hiljaisuuksien tarkasteleminen on antoisaa ja käsikirjan monissa tekstianalyyseissa keskitytään myös siihen, mitä ei kerrota. Pohdin, olisiko traumakertomuksien hiljaisuuksien, aukkojen tai kuulematta jäävien äänien käsittelyä voinut tuoda vielä enemmän teoksen rikkaaseen teoreettiseen osuuteen.

\section{Kaarna Tuomenvirta}

